\title{
Effect of graphene oxide additive on the structure of composite cellulose fibers*)
}

\author{
Tobiasz Gabryś(1)**), Czesław Ślusarczyk ${ }^{1)}$ \\ DOI: dx.doi.org/10.14314/polimery.2020.9.7
}

\begin{abstract}
The paper presents results of investigations on the effect of the addition of graphene oxide (GO) on the structural properties of composite cellulose fibers (CEL). GO/CEL fibers were obtained from a solution of CEL in ionic liquid - 1-ethyl-3-methylimidazole acetate - with the addition of GO dispersion in DMF. A classic wet spinning method was used using water and methanol as coagulants. Results have shown that the addition of GO increases the crystallinity of fibers to $31-40.8 \%$. Moreover, these results indicate a significant impact of the coagulant used in the fiber forming process. Methanol coagulated fibers have greater porosity and larger pore sizes than water coagulated fibers.
\end{abstract}

Keywords: cellulose, graphene oxide, ionic liquids, composite fibers, WAXS, SAXS.

\section{Wpływ dodatku tlenku grafenu na strukturę kompozytowych włókien celulozowych}

Streszczenie: Przedstawiono badania wpływu dodatku tlenku grafenu (GO) na właściwości strukturalne kompozytowych włókien celulozowych (CEL). Włókna GO/CEL otrzymywano z roztworu CEL w cieczy jonowej - octanie 1-etylo-3-metyloimidazolu - z dodatkiem dyspersji GO w DMF. Zastosowano klasyczną metodę formowania włókien na mokro z zastosowaniem wody oraz metanolu jako koagulantów. Badania wykazały, że dodatek GO wpływa na wzrost stopnia krystaliczności włókien do wartości 31-40,8\%. Ponadto wyniki te wskazują na znaczny wpływ koagulantu stosowanego w procesie formowania włókien na ich strukturę. Włókna koagulowane metanolem mają większą porowatość i większe rozmiary porów niż włókna koagulowane wodą.

Słowa kluczowe: celuloza, tlenek grafenu, ciecz jonowa, włókna kompozytowe, WAXS, SAXS.

Cellulose (CEL) is an available, low-cost and biodegradable polymer that can be processed from the following systems: $\mathrm{N}$-methylmorpholine- $\mathrm{N}$-oxide (NMMO), ionic liquids (ILs), $\mathrm{LiCl} / \mathrm{N}, \mathrm{N}$-dimethylacetamide (LiCl/DMAc), $\mathrm{NaOH}$ aqueous solution, alkali/urea and $\mathrm{NaOH} /$ thiourea aqueous solution, tetrabutyl ammonium fluoride/ dimethyl sulfoxide system (TBAF/DMSO), metal complex solutions and molten inorganic salt hydrates [1].

IL dissolves cellulose relatively easily and the regeneration of this biopolymer occurs under the influence of polar solvents [2, 3]. One of the best ionic liquids for dissolving cellulose is 1-ethyl-3-methylimidazolium acetate (EMIMAc) which belongs to the room temperature ionic liquids (RTILs) group [2]. Literature describes the condi-

\footnotetext{
1) University of Bielsko-Biala, Faculty of Materials, Civil and Environmental Engineering, Institute of Textile Engineering and Polymer Materials, Willowa 2, 43-309 Bielsko-Biala, Poland.

*) Material contained in this article was presented at the XI International Conference on "X-ray Investigations of Polymer Structure", 3-6 December 2019, Ustroń, Poland.

**) Author for correspondence: tgabrys@ath.bielsko.pl
}

tions for dissolving cellulose in EMIMAc and then forming it in different forms $[4,5]$.

Cellulose in the form of a solution can be modified by the introduction of organic additives, inorganic additives (e.g. silver [6, 7], silicon [8]) or polymers, resulting in composites. An interesting and modern addition is graphene oxide (GO). In its structure it has many different oxygen function groups [9-11] which make it easier to disperse with different solvents $[12,13]$. These groups also facilitate the dispersion of GO in polymers with functional groups [10, 14], including cellulose.

This paper presents research on the effect of the GO additive on the structure of GO/CEL composite fibers. The fibers were formed by wet spinning method using spinning solutions of cellulose and the additive in ionic liquid 1-ethyl-3-methylimidazolium acetate (EMIMAc). The process of fiber formation, consisting of extrusion spinning liquid into different baths: water (1) and methanol (2), was described in previous work [15] and was similar to that described in the literature [6]. The CEL and composite GO/CEL fibers obtained in this way differed in structural properties depending on the amount of GO in the cellulose matrix and the type of coagulant used. Crystallinity 
of the cellulose matrix was investigated by means of the Wide Angle X-ray Scattering (WAXS) method, whereas an analysis of the porous structure of that matrix by means of the Small Angle X-ray scattering (SAXS) method. Using this method, the pore dimensions and the pore volume fraction were determined. The studies characterize pore sizes on length scales from $1 \mathrm{~nm}$ to $60 \mathrm{~nm}$, according to the resolution of the SAXS equipment used.

\section{EXPERIMENTAL PART}

\section{Materials}

Cellulose long fibers C 6663 and 1-ethyl-3-methylimidazolium acetate (EMIMAc) 97\% (w/w) purity were purchased from Sigma-Aldrich Sp. z o.o. (Poznań, Poland). Methanol 99.8\% and N,N-dimethylformamide (DMF) were purchased from Avantor Performance Materials Poland S.A. (Gliwice, Poland). All the chemicals were used without further purification.

\section{Preparation of spinning solutions and fibers spinning}

GO/CEL fibers were produced using the wet spinning method. For this purpose single syringe infusion pump KDS-100 (KD Scientific Inc. Holliston, USA), equipped with a $10 \mathrm{~cm}^{3}$ syringe and a needle with an internal diameter of $0.7 \mathrm{~mm}$, was used. The monofilament extrusion rate was $23 \mathrm{~cm} / \mathrm{min}$ and the stretch ratio was $S=1$. The fibers were extruded at room temperature directly into a bath containing distilled water or methanol. The coagulation process lasted 30 minutes, and after that the fibers were taken up onto a spool and dried with air at $60^{\circ} \mathrm{C}$. The process of preparation of spinning solutions and the method of obtaining fibers are describe in our unpublished work [16]. The mass composition of ingredients needed to prepare individual spinning solutions and sample description system are listed in Table 1.

$\mathrm{T}$ a b l e 1. The composition of the solutions for the fibers spinning and description system

\begin{tabular}{l|c|c|c|c|c}
\hline $\begin{array}{c}\text { Determination of the spin- } \\
\text { ning solution }\end{array}$ & 0 & A & B & C & D \\
\hline W/w conc. of GO in fiber, \% & 0 & 0.21 & 0.50 & 0.98 & 1.97 \\
W/w conc. of CEL in fiber, \% & 100 & 99.79 & 99.50 & 99.02 & 98.03 \\
\hline Type of coagulant & \multicolumn{5}{c}{ Designation } \\
Distilled water & \multicolumn{5}{|c}{1} \\
Methanol & 2 \\
\hline
\end{tabular}

\section{Methods of testing}

\section{WAXS measurements}

Wide Angle X-ray Scattering (WAXS) investigations were carried out with a URD-65 Seifert (Germany) diffrac- tometer using the reflection method in Bragg-Brentano geometry. CuK $\alpha$ radiation was used at $40 \mathrm{kV}$ and $30 \mathrm{~mA}$. Monochromatization of the beam was obtained by means of a graphite crystal monochromator placed in the diffracted beam path. A scintillation counter was used as a detector. Investigations were performed in the $2 \theta$ angle range of 3 to $60^{\circ}$ in steps of $0.1^{\circ}$. Before measurements fibers were powdered using Hardy's microtome.

\section{SAXS measurements}

The Small Angle X-ray scattering (SAXS) measurements were carried out with the compact Kratky camera, equipped with the SWAXS optical system of HECUSMBRAUN (Austria). The $\mathrm{Cu}$ target $X$-ray tube, operated at: $U=30 \mathrm{kV}, I=20 \mathrm{~mA}$ was used as a radiation source $(\lambda=0.154 \mathrm{~nm})$. The primary beam was monochromatized by Ni filter and a pulse-height discrimination. Measurements were made on powdered fibers, i.e. the same samples as in WAXS tests. The SAXS data were collected as a function of the scattering vector $q=(4 \pi / \lambda) \sin \theta$, where $2 \theta$ is the scattering angle. The moving slit method [17] was applied for determination of the transmittance factor of the sample. The sample holder background was subtracted from the SAXS curves and next curves were corrected taking into consideration both sample thickness and transmittance. The data were converted to absolute intensities with a calibrated Lupolen ${ }^{\circledR}$ (polyethylene) standard [18].

\section{RESULTS AND DISCUSSION}

The available literature shows the presence of several varieties of crystalline cellulose, differing in the shape of an elementary cell and parameters [19]. Native cellulose is known as cellulose type I. On the other hand, cellulose regenerated after dissolving in EMIMAc and then precipitating in the form of fiber in water and methanol has the characteristics of cellulose II. This is a phenomenon known as the dissolving effect of cellulose in most known solvents and the occurrence of so-called hydratecellulose. The crystalline level test was performed for GO/CEL fibers with different GO content.

A variety of crystalline cellulose II was found in the supramolecular structure of all GO/CEL fibers tested. It is significantly higher and better shaped for fibers coagulated in water. The characteristic peak at $2 \theta$ angle $12^{\circ}$ does not occur at all in fibers coagulated in methanol (Fig. 1).

Similar results were obtained by other researchers who precipitated cellulose in distilled water and ethanol [20]. Their WAXS studies indicate that the selection of coagulant significantly affects the supramolecular structure of the regenerated cellulose.

The degree of crystallinity of GO/CEL composite fibers was determined by WAXS curve analysis. To this end, each WAXS diffractogram was deconvoluted into indi- 

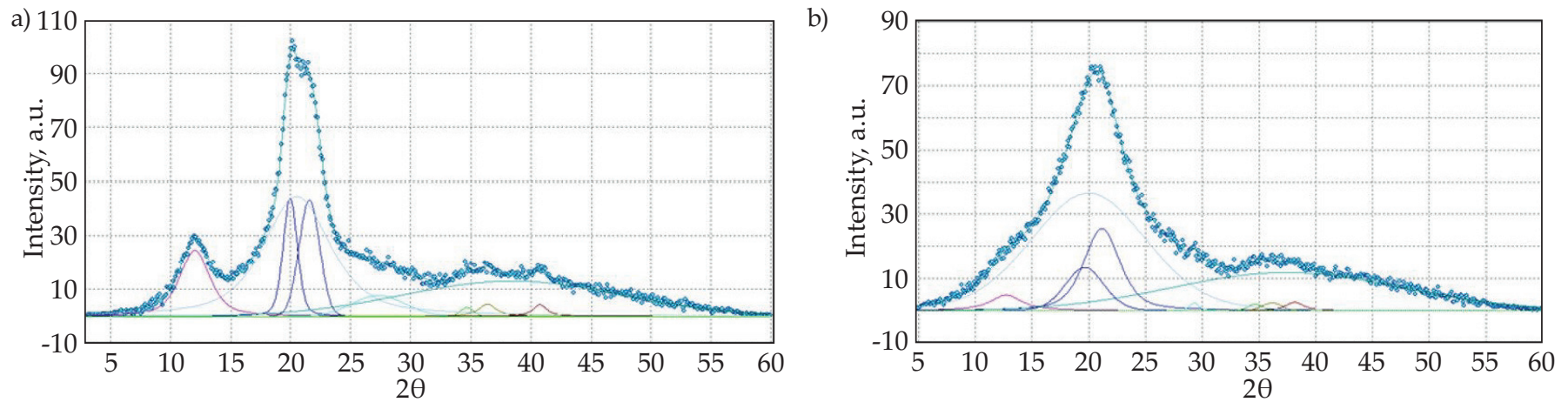

Fig. 1. Crystalline and amorphous components distribution for fiber sample: a) coagulated in water, b) coagulated in methanol

vidual crystalline and amorphous components using WaxsFit software [21]. The shape of each peak was approximated using Gauss and Cauchy function. Examples of deconvoluted diffraction pattern for coagulated fibers in water and methanol are shown in Fig. 1. The degree of crystallinity was determined as the ratio of the summary of the surface fields below the crystalline peaks to the total surface area below the scattering curve.

Studies show that the crystallinity of the fibers obtained in water was between 31 and $40.8 \%$ and fibers from methanol between $21.6-26.2 \%$ (Fig. 2). The analysis of the results obtained also indicates an increase in the degree of crystallinity as the GO content in the cellulose matrix increases, as shown in Fig. 2. It is also important that all coagulated fibers in methanol have a lower degree of crystallinity compared to the fibers obtained in water. This is due to the coagulation rate. Longer coagulation time - in the case of water - promotes the formation of a crystalline structure. The increase in the crystallinity is the most intense for fibers with the GO content of up to $0.5 \mathrm{wt} \%$. In the case of fibers with the GO content more than $0.5 \mathrm{wt} \%$, the degree of crystallinity increases slowly. This may indicate that there is no need for higher concentrations of graphene oxide, because the most available function groups in the cel-

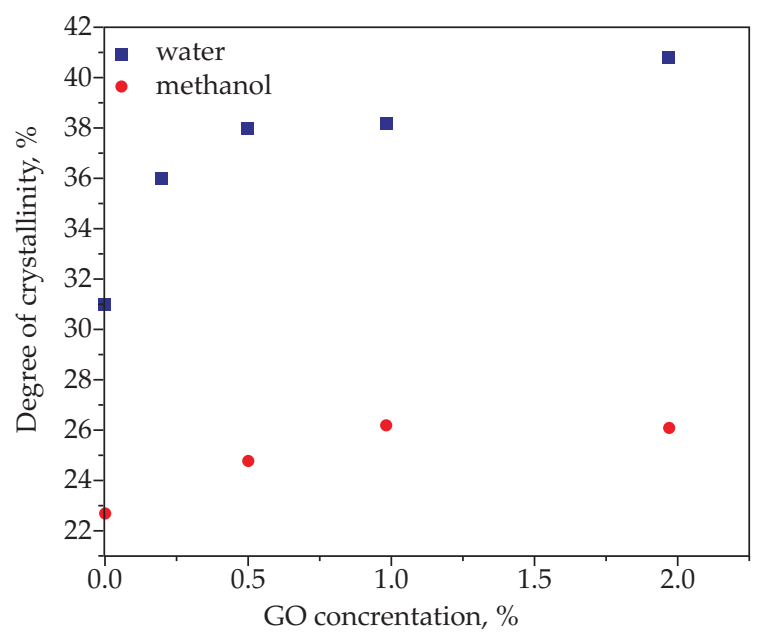

Fig. 2. Dependence of the degree of crystalline on the type of coagulant and the content of graphene oxide in GO/CEL fibers; parameters determined by WAXS curve analysis lulose chain are taken by GO. The increase in the degree of crystallinity with the increase of GO content in the fibers may be conditioned by the presence of numerous hydrogen bonds formed by the combination of cellulose and graphene oxide. These bonds, by linking cellulose, chains together, can form some ordered areas, called lamellas.

The SAXS patterns of investigated fibers are shown in Fig. 3. The dominant feature of these patterns is the appearance of the scattering maximum which can be interpreted based on the standard theory of X-ray scattering at small angles. According to this theory small-
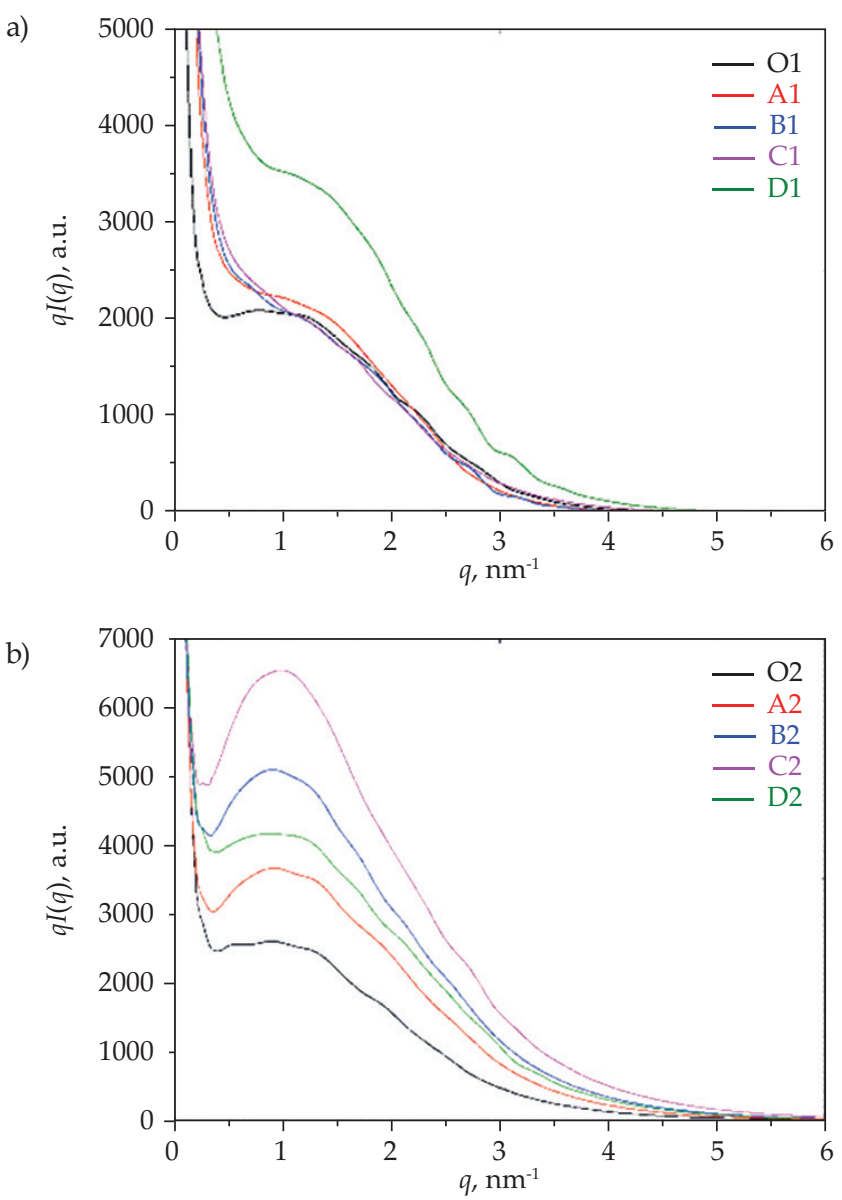

Fig. 3. SAXS patterns for pure cellulose fibers (black) and fibers spun with addition of GO (other colors, respectively): a) coagulated in water, b) coagulated in methanol 
angle X-ray scattering is conditioned by the existence of the electron density in homogeneities in the sample, which in the case of fibers studied is due to the existence of pores in them, the higher intensity is caused by higher content of the pores in these fibers.

Content of pores can be determined by calculating the so-called the scattering power, or invariant $Q$, using the equation:

$$
Q=\int_{0}^{\infty} q^{2} I(q) \mathrm{d} q=\varphi(1-\varphi)(\Delta \varrho)^{2}
$$

where $I(q)$ - the corrected SAXS intensity, $\varphi$ - the volume fraction of pores, $\Delta Q-$ the electron density difference between the pores and cellulose. The pores may be assumed to be entirely air filled in dry fibers. The electron density difference between cellulose and pores was calculated to be $\Delta \mathrm{Q}=511$ electrons $/ \mathrm{nm}^{3}$ [22]. The $\varphi$ values calculated by the Eq. (1), shown in Table 2, indicate a slight but clear influence of the coagulant used in the fiber forming process.

T a b l e 2. The volume fraction of pores $(\varphi)$ and the radii of pores $(R)$ obtained by SAXS

\begin{tabular}{c|c|c|c}
\hline Sample & $\varphi, \%$ & $q_{\text {max }} \mathrm{nm}^{-1}$ & $R, \mathrm{~nm}$ \\
\hline 01 & 0.40 & $0.91 \pm 0.05$ & $6.36 \pm 0.35$ \\
A1 & 0.52 & $1.05 \pm 0.05$ & $5.52 \pm 0.26$ \\
B1 & 0.52 & $0.99 \pm 0.07$ & $5.80 \pm 0.42$ \\
C1 & 0.53 & $1.01 \pm 0.06$ & $5.70 \pm 0.34$ \\
D1 & 0.90 & $1.09 \pm 0.05$ & $5.31 \pm 0.24$ \\
02 & 0.51 & $0.82 \pm 0.05$ & $7.06 \pm 0.43$ \\
A2 & 0.70 & $0.95 \pm 0.04$ & $6.06 \pm 0.26$ \\
B2 & 0.94 & $0.90 \pm 0.05$ & $6.37 \pm 0.36$ \\
C2 & 1.20 & $0.96 \pm 0.04$ & $5.99 \pm 0.25$ \\
D2 & 0.84 & $0.94 \pm 0.04$ & $6.15 \pm 0.27$ \\
\hline
\end{tabular}

For all types of fibers, the values of this parameter are higher for fibers coagulated in methanol. Furthermore $\varphi$ value oscillating around $1 \%$, allow the assumption that in terms of SAXS theory, the investigated fibers can be treated as dilute system of pores dispersed in a cellulose matrix. For such system, we may assume that the scattering intensity is the sum of scattering intensities coming from the individual pores [23]. Experimentally recorded distribution of the scattering intensity for this system is the basis for the calculation of the sizes of individual pores, because the intensity for spherical particle of radius $R$ scattering $\mathrm{X}$-rays is given by Equation (2):

$$
I(q)=9(\Delta \varrho)^{2} V^{2}\left[\frac{\sin (q R)-q R \cos (q R)}{(q R)^{3}}\right]^{2}
$$

where $V$ - the volume of the particle.

The first two maxima are located at an angle satisfying the relations

$$
q_{i} R=\left\{\begin{array}{l}
5.765 \text { for } i=1 \\
9.100 \text { for } i=2
\end{array}\right.
$$

The calculated values of the radii of pores and the position of the maxima $\left(q_{\max }\right)$ are presented in Table 2. Again, the pore sizes in all methanol coagulated fibers are larger than sizes in water coagulated fibers. For the first type of fibers, the value of $R$ is greater than $6 \mathrm{~nm}$, while for the second type of fibers are less than this value. The difference in pore sizes can be seen both for CEL as GO/CEL fibers.

\section{CONCLUSIONS}

This work examines the effect of the coagulant type and the GO additive on the structural properties of composite cellulose fibers. The fibers were formed by wet spinning method from GO/DMF/CEL/EMIMAC solution in distilled water and methanol.

Studies have shown that the coagulant type has a significant impact on the structural properties of CEL and GO/CEL fibers. Namely, the formation of fibers in distilled water (0-1; A-1; B-1; C-1; D-1) results in fibers with higher degree of crystallinity, which is $31-40.8 \%$, because distilled water slows down coagulation process, making it possible to self-assembly crystalline structure. In contrast, fibers coagulated in methanol (0-2; A-2; B-2; C-2; D-2) have a less perfect crystalline structure and the degree of crystallinity of $21.6-26.1 \%$.

Results has shown also that the crystallinity of composite fibers increases with the GO content in the CEL matrix. The observed phenomenon may be the result of the formation of many hydrogen bonds between GO and CEL, which can create certain clusters of ordered areas. Moreover, methanol coagulated fibers are characterized by greater porosity and larger pore sizes than water coagulated fibers.

\section{REFERENCES}

[1] Wang S., Lu A., Zhang L.: Progress in Polymer Science 2016, 53, 169. http://dx.doi.org/10.1016/j.progpolymsci.2015.07.003

[2] Isik M., Sardon H., Mecerreyes D.: International Journal of Molecular Sciences 2014, 15, 11922. http://dx.doi.org/10.3390/ijms150711922

[3] Pinkert A., Marsh K.N., Pang S., Staiger M.P.: Chemical Review 2009, 109, 6712. http://dx.doi.org/10.1021/cr9001947

[4] Fukaya Y., Hayashi K., Kim S.S., Ohno H.: Proceedings of the ACS Symposium Series 2010, 1033, 55. http://dx.doi.org/10.1021/bk-2010-1033.ch002

[5] Ries M.E., Radhi A., Keating A.S. et al.: Biomacromolecules 2014, 15, 609. http://dx.doi.org/10.1021/bm401652c

[6] Rac-Rumijowska O., Fiedot M., Karbownik I. et al.: Cellulose 2017, 24, 1355. 
http://dx.doi.org/10.1007/s10570-016-1168-7

[7] Rac-Rumijowska O., Maliszewska I., Fiedot-Toboła M. et al.: Polymers 2019, 11, 562. http://dx.doi.org/10.3390/polym11030562

[8] Andersson Trojer M., Olsson C., Bengtsson J. et al.: Journal of Colloid and Interface Science 2019, 553, 167. http://dx.doi.org/10.1016/j.jcis.2019.05.084

[9] Guerrero-Contreras J., Caballero-Briones F.: Materials Chemistry and Physics 2015, 153, 209.

http://dx.doi.org/10.1016/j.matchemphys.2015.01.005

[10] Ghosh T., Biswas C., Oh J. et al.: Chemistry of Materials 2012, 24, 594. http://dx.doi.org/10.1021/cm2033838

[11] Teodoro K.B.R., Migliorini F.L., Facure M.H.M., Correa D.S.: Carbohydrate Polymers 2019, $207,747$. http://dx.doi.org/10.1016/j.carbpol.2018.12.022

[12] Konkena B., Vasudevan S.: The Journal of Physical Chemistry Letters 2012, 3, 867. http://dx.doi.org/10.1021/jz300236w

[13] Paredes J.I., Villar-Rodil S., Martínez-Alonso A., Tascón J.M.D.: Langmuir 2008, 24, 10560. http://dx.doi.org/10.1021/la801744a

[14] Hwang T., Oh J.-S., Yim W. et al:: Separation and Purification Technology 2016, 166, 41. http://dx.doi.org/10.1016/j.seppur.2016.04.018
[15] Fryczkowska B., Wiechniak K.: Polish Journal of Chemical Technology 2017, 19, 41. http://dx.doi.org/10.1515/pjct-2017-0066

[16] Gabryś T., Fryczkowska B., Biniaś D. et al.: Carbohydrate Polymer, in print.

[17] Stabinger H., Kratky O.: Die Makromolekulare Chemie 1978, 179, 1655. https://doi.org/10.1002/macp.1978.021790630

[18] Kratky O., Pilz I., Schmitz P.J.: Journal of Colloid Interface Science 1966, 21, 24. https://doi.org/10.1016/0095-8522(66)90078-X

[19] Zugenmaier P.: "Crystalline cellulose and cellulose derivatives, characterization and structure", (Eds. Timell T.E., Wimmer R.), Springer Series in Wood Science, Heidelberg 2008.

[20] Surma-Ślusarska B., Danielewicz D., Kaleta M.: Przeglad Papierniczy 2012, 68, 99.

[21] Rabiej M.: Journal of Applied Crystallography 2017, 50, 221. http://dx.doi.org/10.1107/S160057671601983X

[22] Crawshaw J., Cameron R.E.: Polymer 2000, 41, 4691. https://doi.org/10.1016/S0032-3861(99)00502-9

[23] Porod G.: "Small-Angle X-ray Scattering" (Eds. Glatter O., Kratky O.), Academic Press, New York 1982, pp. 17-51.

Received 16 III 2020 